\title{
Understanding the Roles and Responsibilities of Deputy School Heads in Primary Schools in Botswana
}

\author{
Philip Bulawa \\ University of Botswana, Faculty of Education, \\ P/Bag 00702, Gaborone, Botswana. \\ Mavis B. Mhlauli \\ University of Botswana, Faculty of Education \\ P/Bag 00702, Gaborone, Botswana.
}

\begin{abstract}
The position of deputy school head has in recent years attracted the attention of researchers and debate globally (Cranston, 2007). Deputies, in their individual capacity or collectively working with other members of the school management, perform a variety of tasks that contribute to the day-to-day operation of the school. As would be expected, they work very closely with school heads, who have increased delegation of responsibility to deputy heads (Kwan \& Walker, 2008). In Botswana as in other countries, deputy school heads play a very significant role in the management of schools. They are actively involved in a broad range of school responsibilities that include the function of head of academics and those delegated to them by school heads. In spite of the significance of their leadership and management school functions, their perspective of the role and responsibilities they perform have not been subjected to any extensive research. This exploratory study sought the views of primary deputy school heads about their role and responsibilities as members of the school management team. The study adopted heuristic case study design and semi-structured interviews were used to collect data. The sample of the study consisted of fifty deputy school heads. Data were analysed inductively using themes. The findings of the study show that they are aware of what their duties entail. The conclusion drawn from the study is that deputy-school heads are overwhelmed with duties that are not part of their job description. The study recommends that their duties be confined mainly to their job description to give them more time to focus on the supervision of teaching and learning, which is their core business. The findings of the study have implications for research and practice.
\end{abstract}

Key words: Botswana, Primary Schools, Deputy School-Heads, Responsibilities, leadership, Quality.

\section{BACKGROUND TO THE STUDY}

Globally schools have undergone an array of reforms and changes such as school-based management (Cranston, Tromans, \& Reugebrink, 2004). Therefore, school leadership and management functions, carry with them increased responsibilities and accountabilities for everyone working in schools, under the leadership of the school head (Yu-kwong \& Walker, 2010). They are expected to among other responsibilities, have vision of where they want their schools to go as well as communicate to others a clear sense of direction of how to reach their goal (Lewis \& Murphy, 2008). Among those in school leadership are deputy school heads who are the focus of this study. In other countries titles such as deputy principal, vice-principal and assistant principal (Cranston, 2007; Wong, 2009) are used to refer to the position of deputy school head officially used in Botswana (Bulawa, 2013). 
Leadership and management of schools in Botswana has become a major challenge for members of the school senior management team (SMT) which is tasked with the responsibility of ensuring effective teaching and learning. As key members of the SMT, deputy school heads represent the largest pool of future school heads (Cranston, 2007; Lee, Kwan \& Walker, 2009; Pheko, 2010; Yu-kwong \& Walker, 2010). In their current position, they have a broad range of responsibilities to play. As heads of academics, these include leadership role in the provision of continuous professional development (CPD) (Bulawa, 2011), and "ensuring the quality of continued school-based teacher development activities” (Pansiri, 2008, p. 472).

An insight of the expected duties of deputy school heads in Botswana is revealed in a Ministry of Education and Skills Development (2015) advertisement for the position of deputy school head for secondary schools. The main purpose for the job is that of the provision of assistance to the school head to efficiently organise, administer and control school together with its members of staff and students to achieve the intended goals and objectives. Other listed duties include coordination of the invigilation of examinations; provision of different learning materials and resources for use by the school; planning, preparation, and delivery of instructional activities aimed at facilitating active learning experiences. The position also requires deputy school heads to coordinate parents and teachers meetings, and promote the values and achievements of the school to the community.

The same advertisement stipulates that they are required to assist school heads in important areas of leadership and management as liaising with teaching and non-teaching staff members in developing and driving the vision, mission and strategic plans of the school; coordination of the drawing of the school timetable; provision of guidance of the implementation of schoolbased performance improvement initiatives; and observation of teachers' lessons; and networking with in-service Education Officers on professional development. As pointed out by Wong (2009), elsewhere deputy school heads also have key responsibilities that are determined and delegated to them by school heads.

The Ministry's requirements correspond with some of the functions of deputy school heads as reflected in Bulawa's (2011) study, they are supposed to work collaboratively with other members of senior management team, in the implementation of education reforms, school discipline and other essential school roles they may be delegated by school heads to perform on their behalf (Bulawa, 2011). The views of deputy school heads as reflected in this study are therefore significant to determine if indeed their perspective of the roles and responsibilities they perform tally with the Ministry's specified job requirements, as well as their practical experience of these job requirements.

Notwithstanding the pivotal role they play in school leadership and management, in Turkey for instance, there are reports of limited research on vice-principals, which makes it difficult to know much about their opinions regarding their jobs and work lives (Beycioglu, Ozer, \& Ugurlu, 2012). This is in spite of research evidence that this position is regarded as a pipeline to the position of school head (Munoz \& Barber, 2011), and that they constitute the largest pool of future school heads.

It is apparent in the literature, that globally the position of deputy school head, or viceprincipal as they are referred to in other countries, has attracted less research interest, and has not been widely debated (Beycioglu, Ozer, \& Ugurlu, 2012). These concerns are also true of Botswana, as most studies by local scholars such as Moswela (2010), Pheko (2008), and Pansiri (2008) on school leadership and management are focused on school heads with minimal reference to deputy school heads' role and responsibilities. 


\section{Research Questions}

The research questions guiding this study were:

1. What is the extent to which participants understand their role as deputy school heads?

2. How are participants satisfied with their role as deputy school heads?

3. What challenges do participants encounter in the performance of their role?

\section{THEORETICAL FRAMEWORK}

The experiential learning theory (ELT) developed by Kolb in 1984 serves "as the theoretical framework for this study" (Munoz \& Barber, 2011, p. 133). ELT is one of the most influential theories of management learning (Kayes, 2002), which defines learning as a process by which knowledge is created through the transformation of experience (Boyatzis \& Kolb, 2002). One of its cornerstones is the engagement of students in a process that would best enhance their learning and that in this process there should be feedback on the effectiveness of students' learning efforts (Kolb \& Kolb, 2005). Further emphasised by Kolb and Kolb (2005) is that learning as a holistic process involves "the integrated functioning of the total person-thinking, feeling, perceiving, and behaving" (p.194).

It is against this background that participants in this study, who are deputy school heads and full time students pursuing a two-year in-service Bachelor of Educational Leadership and Management (BELM) programme with the University of Botswana, are given oportunity "to reflect critically on their assumptions and beliefs" (Kayes, 2002, p. 138) regarding their experience as school managers. It is important that their voices as deputy school heads should be heard as to have an insight of how they feel about their job. As in-service students at the University of Botswana, their views contribute to the enrichment of their leadership and management courses.

As argued by Kayes (2002), using participants' experience is bound to help them to develop more holistic perceptions of themselves. This experiential approach to learning has potential to in future improve the nature of deputy school heads' leadership and managerial work in schools. A study by Day (2000) suggests that successful school leaders need to engage in a variety of reflective practices during their careers, asserting that in doing so they among other things, "develop and maintain their critical thinking and emotional intelligence" (p. 113). By engaging in reflective practices, deputy school heads involve themselves in "the process of selfdiscovery and questioning that leads managers to develop a comprehensive view of managerial practice" (Kaye, 2002, p. 138). Exploring the views of deputy school heads is also significant to ensure that training and development for leadership and management functions of these school leaders respond to the needs of their schools (Kolb, Lublin, Spoth, \& Baker, 1986).

\section{LITERATURE REVIEW}

Globally deputy school heads play pivotal roles and responsibilities which have been changing from time to time due to frequent and different reforms and restructurings occurring in schools. School management, for instance have encountered change in different areas of their work including, "school management, structural and curriculum changes in recent times" (Cranston, 2007, p. 25). A study by Arar (2014) about deputy principals in Arab schools in Israel, revealed that they have several roles to play including, "personal management, dealing with student issues and channelling communication across the school's different cross sections" (p. 99).

As leaders who hold key positions of leadership in schools, the plethora of reforms in education are bound to enormously impact on deputy school heads in one way or another. In Auckland, New Zealand deputy principals are very busy having to deal with a broad range of 
roles and responsibilities that required them to demonstrate an array of skills and competencies (Cranston, 2007). Similarly, in Hong Kong deputy school heads increasingly find themselves having to take on an assortment of school functions because school heads are unavailable tending "to duties outside the immediate boundaries of their schools" (Yu-kwong \& Walker, 2010, p. 533).

In the state of Kentucky in the USA, the job of assistant principals is reported to be significantly varying, depending on among other things, individual schools and the principal. They are involved in scheduling of classes, management of textbooks and supplies, and coordination of transportation. In their functions they also "handle discipline and attendance issues, maintain records for extra-curricular activities, develop new curriculum, evaluate teachers, supervise custodial and support personnel, deal with community relations, monitor facilities, and maintain the safety of students and staff" (Munoz \& Barber, 2011, p. 132).

While in African countries research on deputy school heads is even more scanty, the little that is available shows that in Kenya deputy school heads play a major role in the management of schools including having to handle matters of discipline. For instance, the literature shows that they are expected to be physically present in school throughout school day to handle student disciplinary issues, making this office "a beehive of activities in discipline management among other duties" (Macharia, Thinguri, \& Kiogo, 2014, p. 201). The issue of student discipline is also illuminated in Lee's, Kwan's and Walker's (2009) study as one of the most common duties undertaken by deputy school heads.

As in other countries, the common practice in Botswana is to appoint school heads who have been deputy school heads (Pheko, 2008). Research provides evidence of government capacity building strategies for deputy school heads together with other SMTs aimed at ensuring that their habits, attitudes and practices are professionally altered such that they are able to enhance and improve learners' level of academic performance (Pansiri, 2008). Although a review of the literature shows a dearth of studies on the views of deputy school heads in Botswana about their roles and responsibilities, negligible research that is available, reveals that they play a key role in the management of schools. For instance, secondary school deputy heads in particular are not required to teach but perform administrative duties (Morapedi \& Jotia, 2011).

A study conducted by Bulawa (2011) in Botswana about the role of school managers in the implementation of the performance management system in schools, shows the importance of deputy school heads in the management of schools, including delegated role in the reform implementation process. School heads often delegate their responsibilities to deputies because the former are involved in other commitments away from their schools. Deputy school heads are the on the ground personnel carrying out many of the responsibilities, including assisting with leadership of the implementation process and in turn reporting to school heads.

The Revised National Policy (RNPE) of 1994 in Botswana singles out the school leadership, including deputies as having to carry out school-based in-service training of their teachers. In doing so, they are required to among other responsibilities, engage in regular teacher observation and school-based workshops and promotion of communication among teachers (Republic of Botswana, 1994). Consistent with the RNPE recommendation, deputy school heads in Botswana consider their role, as including working with others to deliver professional development, overseeing the monitoring of classroom supervision and to be hands-on in the implementation of policies (Bulawa, 2011). 
Notable in the literature, is concern that deputy school heads' management role and responsibilities are generally not clearly defined, with school heads mainly determining their job assignments. Further apparent is however, evidence of responsibilities in which school heads are reluctant to delegate to their deputies, particularly in financial management which they consider to be confidential (Kwan \& Walker, 2008).

It is however, apparent in the literature that though negligible, while globally there have been concerted initiatives to conduct research on deputy school heads' roles and responsibilities (Cranston, 2007), very little has been carried out in Botswana. In an effort to narrow the gap in the literature, this study investigated primary and junior secondary deputy school heads' views about their roles and responsibilities in schools. This was deviation from most studies that tend to provide a normative description of their roles and duties (Kwan \& Walker, 2008). This is significant given that since they constitute the potential pool of school heads, "an understanding of their duties, roles, and feelings would better inform policy-makers and practitioners regarding the formulation of training and development strategies for aspiring" (Kwan \& Walker, 2008, p. 74; Lee, Kwan \& Walker, 2009) deputy school heads.

It is also anticipated that exploring the views of deputy school heads will help better identify their role and the contribution they make to school leadership and management (Wong, 2009). Wong (2009) recognises the significant position that deputies play in school effectiveness, their potential significance in the implementation of school-based management, and their relationship with school heads as fundamental factors that warrant extensive research on these school leaders.

\section{RESEARCH METHODOLOGY}

The study was qualitative and used the heuristic case study design. Heuristic case studies assist in illuminating the reader's understanding of the phenomenon under study as it can bring the discovery of new meaning, extend the reader's experience or confirm what is already known. The may result in there thinking and reconceptualization of the phenomenon under study (Merriam, 1988). A case study design can be used to study a phenomenon systematically and does not claim any particular methods for data collection or data analysis. Therefore, any and all methods can of gathering data can be used in case study (Merriam, 1988).

A case study design is emergent, therefore, the research activity changes as the evaluator gains new insights into the concerns and issues being studied (Gall, Borg \& Gall, 1996). The emergent design is said to be advantageous in that: 1) meaning is to a large extent determined by context; 2) captures multiple realities; 3 ) shows how the outcome of the study is dependent on the interaction between the researcher and context. (Lincoln \& Guba, 1985). This design was chosen because of its peculiarity in studying phenomena that is of interest to the researchers given the current emphasis by The Ministry of Basic Education in Botswana on developing school leadership in order to improve performance in schools.

\section{Research Context}

The study was conducted among in-service deputy school-heads currently studying for a Bachelor of Educational Leadership and Management at the University of Botswana. These are primary deputy school heads who have been promoted to the position of school-head and are responsible for classroom management and supervision in schools including improving performance in schools. 


\section{Population}

The population for this study is drawn from In-service deputy School-Heads for primary schools who are currently enrolled for the BLM program and make up a total of 180 students. These deputy school-heads are drawn from various districts in Botswana hence it is critical to understand their perspectives on their preparedness for the job of deputy school-head.

\section{Sample}

The sample was purposively selected through randomly (Ary, Jacobs, \& Sorensen, 2010) picking a total of 50 students who are from the 2017/18 cohort at the University of Botswana doing their third year. This sample was convenient to the researchers as it allowed them to get a clearer picture of what the students' perspectives and challenges were in performing their roles and duties as school leaders. Though the results of a qualitative findings from this study cannot be generalized to all the schools in Botswana, there is a high possibility of the results be generalized since the deputy school-heads under study were drawn from various districts in Botswana.

\section{Data Collection}

The study used semi-structured interviews to collect data. Berg (2004) has identified reasons for using semi-structured interviews that they; (1) obtain in-depth information on selected topics; (2) obtain personal histories (3) gain cultural knowledge and beliefs (4) describe practices, hence they were found suitable for the study as it explored the deputy school-heads practices and understanding of their roles in schools. Semi-structured interviews are said to be useful in providing certain information desired from all the respondents. Such interviews are guided by a list of questions and such a format allows the researcher to respond to the situation at hand, the emerging worldview of the interviewees, and new ideas on the topic being studied (Merriam, 1988).

\section{Data Analysis and Presentation}

Data were analysed inductively where data collected was transcribed, coded and categorized in order to inform the next interview cycle. Data analysis took place at the same time with data collection and we constantly used the questions raised during transcription to shape the questions for the next interviews. This process allowed us to mine the data thoroughly in order to exhaust all possible gaps. Pseudonyms were used to protect the confidentiality and anonymity of the participants. Data were presented thematically according to the research questions.

\section{Trustworthiness of the Research}

Establishing the trustworthiness of a research lies at the heart of conventional methods such as validity and reliability often associated with quantitative research (Lincoln \& Guba, 1985). For the trustworthiness of this study, transferability and peer debriefing were used. Transferability is basically achieved by providing a detailed rich description of the setting such that readers are given sufficient information to be able to judge the applicability of findings to other settings that they know. The use of peer debriefing allowed us as a researchers to be honest by challenging those suppositions that led to our interpretations as well as prejudices, biases and the ability to seek meaning and clarifications (Mhlauli, 2010).

\section{RESEARCH FINDINGS AND DISCUSSIONS}

The research findings presented are in response to all the four research questions. Several themes that emerged from the findings include; what the role of deputy school head entails; what deputy school heads' job description entails; deputy school heads' job description and additional responsibilities; and the nature of additional responsibilities all of which responded 
to the research question: What is the extent to which participants understand their role as deputy school heads? The second research question: How are participants satisfied with their role as deputy school heads? and third question: What challenges do participants encounter in the performance of their role?; were addressed by the theme to do with challenges participants confront trying to perform their duties as deputy school heads.

\section{Deputy School-Heads' Understanding of what their role Entails}

It was important that this study established what participants perceived as the roles they should play in their position of deputy school head. As noted Arar's (2014) study about Arab's schools in Israel, and that of Macharia, Thinguri, and Kiogo (2014) in Kenya, in Botswana participants' revealed that their roles were varied, with almost all of them seeing themselves mainly as heads of academics. One participant explained that the role of head of academics includes supervision of staff and monitoring of all initiatives to do with teaching and learning. Another one expressed a similar sentiment that as head of academics, one is "responsible for the effectiveness of teaching and learning." There was a participant who stated: "As a deputy school head I play a vital role in the institution I'm attached to which are as follows: I work closely with the school on management issues; I'm also head of academics; I supervise teaching \& learning." A similar understanding of the role of head of academics, is that of "supervising teachers; observing teaching and learning processes; and capacitating teachers to equip them with skills they need." Finally, one participant summed it thus: "Academic performance rests upon my shoulders."

Few participants' who saw their role as deputy school heads from the management or administrative viewpoint, did so in relation mainly to academics, finance, and professional development. One commented: "Managing academics; coordinating staff development; and managing finances." Another one explained that for her it was mainly an administrative duty with a focus on academic performance of learners. In the following comment, a participant maintained that the role of a "deputy school head is to manage a school; help teachers in their teaching areas; and also responsible for learners to take their studies serious."

\section{Deputy School Heads' Job Description Entails}

It was important that following participants' revelations about their role, the study should establish from participants, deputy school heads' role and responsibilities as documented in their job description. It emerged from the findings that while there is a broad range of other duties to be performed by deputy school heads, staff development, and teaching and learning remain outstanding. One participant maintained: "My job description talks mostly about staff development" while others explained respectively: "It entails mentoring; coaching capacitating staff and inducting staff"; "I am head of academics responsible for tests and exams"; and "I head academics and am a staff development coordinator;" and "I am head of academics and running school-based workshops."

Many participants revealed that one of their functions is to deal with issues of finance. One participant in this category stated: "Deputies coordinate all school funds," while another one pointed out that deputy school heads are "responsible for school finances." Other comments pertaining to deputies describe them as "school finance officer," who "oversee financial administration," "handle school funds" and "collect school finances."

Participants also indicated that deputy school heads in primary schools are required to teach, with one stating "teaching a class"; assessment of teachers"; "checking syllabus coverage versus pupils' work"; and "management of school curriculum" as some of the duties reflected in the job description. Another participant maintained: "I also have a class to teach." 
Further highlighted by participants is to do with overseeing transfer of students in and out of school. A participant pointed out that deputy school heads are required to supervise and monitor transfer in and out of school," while another one mentioned "admitting and transferring learners" as a significant duty stated in the job description. Beside admission and transfer of students, deputies are required to act in the absence of school leads. Comments such as a deputy school head has to "stand in for the school head during his/her absence;" "my job description entails that I act as school head during the absence of the school head." In is also highlighted in the literature that deputy school heads' job descriptions have been found generally unclearly defined, with school heads mainly deciding their duties (Bulawa, 2011; Kwan \& Walker, 2008). Other duties listed management of school records, supervision of heads of departments, presiding over meetings, assessing teachers, school stock officer and instructional supervision.

The functions highlighted by participants in this study are consistent with deputies elsewhere such as those in Kentucky in the United States of America, are reported to have also performed different duties. These include disciplinary issues, evaluation of teachers, maintenance of the safety of students and staff, just to mention a few (Munoz \& Barber, 2011).

\section{Additional Responsibilities of Deputy School Heads}

The participants were asked about other exigencies of the job deputy school heads were required to undertake. Almost all participants indicated that they were doing additional duties outside their job description. Yu-kwong and Walker (2010) also to refer to different school functions deputy school heads have to perform in the absence of school heads who would be unavailable due to other duties outside their schools.

Within the school such duties include involvement in sports activities, with participants indicating that they were actively involved in such activities as coaching of ball sports and athletics. They also reported that they were required to play a major role in the supervision of support staff such as cooks, general duty assistants and security personnel. Others include coordination of Parents Teachers Association (PTA) committee; as well as coordination of house committees and what one participant termed handyman projects.

Outside the school they had social responsibility having to work with members of the community, in some cases purely on advisory role on a wide range of community development activities. Furthermore, were intergovernmental activities which required deputy school heads to work with other public officers to implement government initiatives to provide service to the public. Several of them indicated that they were members of the anti-corruption committee.

\section{Challenges Deputy School Heads face in the Performance of their Duties}

The findings reveal some challenges that deputy school heads face in their day to day management of schools. The literature also reveals evidence of challenges they confront in their work. These include evidence of a study on deputy principals in Auckland, New Zealand (Cranston, 2007), and deputy school heads in Hong Kong (Yu-kwong \& Walker, 2010).

The major challenge that emerged was the concern about work overload characterised mainly by the requirement to simultaneously perform their management duties and teaching role. The following comment represents the views of participants: "Being a class teacher and a deputy head at the same time; having to do all office work as school heads are out for meetings; not going on leave during vacations." Similar voices of concern include such sentiments as; "being a class teacher makes me fail to deliver in many areas"; and "the major problem is to combine 
office work with class teaching, and also being responsible for the entire school academics." Another participant who expressed a similar sentiment stated: "The main challenges are having a class of my own to teach and not having an office to work."

There were others who indicated that from time to time, they found themselves having to perform a broad range of other duties within the school that were outside their job description. For instance, one such challenge was "being a bursar at the same time as head of academics." There was a participant who indicated that when the school head was absent attending official duties, the deputy school head was required to run the school, which included having to attend to individual and collective concerns of teachers, parents and students. The sentiment that these multiple tasks can be counterproductive to the expected effectiveness of deputy school heads is evidence of the general feeling that emerged in the findings.

\section{CONCLUSION AND RECOMMENDATIONS}

The findings reveal that the role and responsibilities of the position of deputy school head is guided by a clearly defined job description and that deputy school heads are aware of what they are required to do. While they appreciated the documented role and responsibilities, they also expressed concern that about other duties they were required to perform out their job description. The findings suggest that it is mainly these extra duties that adversely affected the effectiveness of the execution of their day to day.

Based on the findings, this study recommends that the role and responsibilities of deputy school heads be revisited in view of their concern about work overload. Such workload seems to arise mainly from additional duties they are required to perform which take them away from what should be their official work as outlined in the job description. It is, therefore, the position of this study that in reviewing these duties, priority should be given specifically to the reduction of most additional duties which are perceived as impediments to effective execution of duties. The review could also consider if it is not high time primary deputy school heads are relieved from the teaching responsibility to focus mainly on leadership and management responsibilities.

\section{IMPLICATIONS FOR RESEARCH AND PRACTICE}

This study confined itself to deputy school heads' understanding of their role and responsibilities as outlined in the job description and any additional duties. This warrants further studies on deputy school heads' critical evaluation of their official roles and responsibilities as this would be valuable contribution to research and may inform policy direction in the school management system.

\section{References}

Arar, K. (2014). Deputy-principals in Arab schools in Israel: an era of reform. International Journal of Educational Management, 28(1), 96-113.

Ary, D., Jacobs, L. C., \& Sorensen, C. (2010). Introduction to Research in Education. Wadsworth: Cengage Learning. Berg, B.L. (2004). Qualitative research methods for the social sciences ( $5^{\text {th }}$ Ed). New York: Pearson, Allyn \& Bacon.

Beycioglu, K., Ozer, N., \& Ugurlu, C. T. (2012). The facets of job satisfaction among vice-principals in elementary schools. Journal of Management Development, 31(7), 636-647.

Boyatzis, R. E. \& Kolb, D. A. (2002). Learning Styles and Adaptive Flexibility: Testing Experiential Learning Theory. Management Learning, 33(1), 5-33.

Bulawa, P. (2011). Implementation of the Performance Management System in Senior Secondary Schools in Botswana: The Perspective of the Senior Management Team. Doctoral thesis, School of Education. James Cook University.

Bulawa, P. (2013). Constraints to Senior Management's Capacity to Implement the Performance Management System in Senior Secondary Schools in Botswana. International Education Studies, 6(5), 56-67. 
Cranston, N. (2007). What do we know about middle-level school leaders in New Zealand? An exploratory study of Auckland secondary deputy and assistant principals. New Zealand Journal of Educational Leadership, 22(1), 2007, 16-30.

Cranston, N., Tromans, C., \& Reugebrink, M. (2004). Forgotten leaders: what do we know about the deputy principalship in secondary schools? International Journal of Leadership in Education, 7(3), 225-242.

Day, C. (2000). Effective Leadership and Reflective Practice. Reflective Practice, 1(1), 113-127.

Harvey, M. \& Sheridan, B. (1995). Measuring the perception of the primary school deputy principal's responsibilities. Journal of Educational Administration, 33(4), 69-91.

Kayes, D. C. (2002). Experiential Learning and Its Critics: Preserving the Role of Experience in Management Learning and Education. Academy of Management Learning and Education, 1(2), 137-149.

Kolb, A. Y. \& Kolb, D. A. (2005). Learning Styles and Learning Spaces: Enhancing Experiential Learning in Higher Education. Academy of Management Learning \& Education, 4(2), 193-212.

Kolb, A. Y. \& Kolb, D. A. (2011). Experiential Learning Theory: A Dynamic, Holistic Approach to Management Learning, Education and Development. The Sage Handbook of Management Learning, Education and Development, $42-68$

Kolb, D., Lublin, S., Spoth, J., \& Baker, R. (1986). Strategic Management Development: Using Experiential Learning Theory to Assess and Develop Managerial Competencies. Journal of Management Development, 5(3), 13-24.

Kwan, P. \& Walker, A. (2008). Vice-pricipalship in Hong-Kong: aspirations, competencies, and satisfaction. School Effectiveness and School Improvement, 19(1), 73-97.

Lee, J. C-K., Kwan, P., \& Walker, A. (2009). Vice-Principals: their responsibility roles and career aspirations. International Journal off Leadership in Education, 12(2), 187-207.

Lewis, P. \& Murphy, R. (2008). New directions in school leadership. School Leadership and Management, 28(2), 127-146.

Lincoln, Y. and Guba, E. (1985). Naturalistic inquiry. Beverly Hills CA: Sage

Macharia, J. M., Thinguri, R., \& Kiongo, P. (2014). An Investigation into the Deputy Principals' Preparedness in Discipline Management in Secondary Schools in Kenya. International Journal of Education and Research, 2(6), 199214.

Merriam, S.B. (1988). Case study research in education: A qualitative approach. San Francisco: Jossey-Bass.

Mhlauli,M.B. (2010). Social studies teachers' perceptions and practices for educating citizens in a democracy in upper classes in primary schools in Botswana. Unpublished PhD dissertation. Columbus: The Ohio State University. https://etd.ohiolink.edu/pg_10?0::NO:10:P10_ETD_SUBID:72863

Morapedi, Z. E. \& Jotia, A. L. (2011). Building Democratically Active Citizens Through the Prefectship System in Botswana Schools. Current Issues in Education, 14(1), 1-36.

Moswela, B. (2010). Instructional Supervision in Botswana Secondary Schools. Educational Management Administration \& Leadership, 38(1), 71-87.

Munoz, M. A. \& Barber, H. M. (2011). Assistant principals in high-stakes accountability environments: The effects of job attributes and school characteristics. Education Assessment, Evaluation and Accountability, 23, $131-142$.

Pansiri, N. O. (2008). Instructional Leadership for Quality Learning: An assessment of the Impact of the Primary School Management Development Project in Botswana. Educational Management Administration \& Leadership, $36(4), 471-494$.

Pheko, B. (2008). Secondary school leadership practice in Botswana: Implications for effective training. Educational Management Administration \& Leadership, 36(1), 71-84.

Republic of Botswana (2015). Applications from suitably qualifies and experienced candidates for the post of Deputy School Head at different Secondary Schools (Junior \& Senior) in the country (Reference No. REF: TSM 4/32/9 1 (38) $A D$ RP). Gaborone: Ministry of Education and Skills Development.

Wong, P-M. (2009). A conceptual framework for understanding the working relationship between school principals and vice-principals. School Leadership and Management, 9(2), 157-179.

Yu-kwong, P. K. \& Walker, A. (2010). Secondary school vice principals: commitment, challenge, efficacy and synchrony. British Educational Research Journal, 36(4), 531-548. 